\title{
The woodlouse (Isopoda: Oniscidea) fauna of steppe habitats in the Kostanay region of Kazakhstan
}

\author{
Tatyana M. Bragina ${ }^{1,2}$ \& Dilyara D. Khisametdinova ${ }^{3}$
}

Keywords: terrestrial isopods, fauna, dry steppe, desert steppe, Kostanay Oblast, Northern and Southern Turgai.

Ključne besede: kopenski enakonožci, favna, suha stepa, puščavska stepa, Oblast Kostanaj, severni in južni Turgaj.
Received: 14. 3. 2017

Revision received: 19.9. 2017

Accepted: 18. 1. 2018

\section{Co-ordinating Editor:}

Stephen Venn

\begin{abstract}
This paper presents first materials on the fauna and distribution of the terrestrial isopods - woodlice (Oniscidea) inhabiting the central and southern parts of Kostanay Region (Kazakhstan, Northern and Southern Turgai), located in the steppe zone. Most of the specimens of woodlice were collected in the territory of the National Nature Reserve "Altyn Dala", a new protected area (established in 2012) and in the area of the Naurzum National Nature Reserve (established in 1931, World Heritage Site of UNESCO), on the Stipa lessingiana dry steppe. The list of woodlice includes six species (Crustacea: Isopoda: Oniscidea), belonging to five genera and three families in the study area. Four species are recorded for the first time in Kazakhstan - Desertoniscus subterraneus Verhoeff, 1930, Parcylisticus dentifrons (Budde-Lund 1885), Porcellio scaber Latreille, 1804, and Protracheoniscus major (Dollfus 1903). Distribution characteristics are provided for all of those species recorded in the study area. For the territory of Kazakhstan, according to a literature data, currently 16 species of terrestrial isopods have been recorded.
\end{abstract}

\section{Izvleček}

$\mathrm{V}$ članku predstavljamo prve izsledke o favni in razširjenosti kopenskih enakonožcev - mokric (Oniscidea), ki jih najdemo v osrednjih in južnih predelih regije Kostanay (Kazahstan, severni in južni Turgaj) v območju stepe. Večino osebkov mokric smo nabrali na območju narodnega naravnega rezervata "Altyn Dala”, ki je novo zavarovano območje (od leta 2012) in v območju narodnega naravnega rezervata Naurzum (ustanovljen leta 1931, uvrščen tudi na Seznam svetovne dediščine UNESCO) na suhi stepi z vrsto Stipa lessingiana. Seznam mokric vsebuje šest vrst (Crustacea: Isopoda: Oniscidea), ki pripadajo petim rodovom in trem družinam. Štiri vrste so prvič zabeležene v Kazahstanu Desertoniscus subterraneus Verhoeff, 1930, Parcylisticus dentifrons (Budde-Lund 1885), Porcellio scaber Latreille, 1804 in Protracheoniscus major (Dollfus 1903). Za vse vrste, ki smo jih našli, smo podali značilnosti njihove razširjenosti. V Kazahstanu je v skladu z literaturo znanih 16 vrst kopenskih enakonožcev. 


\section{Introduction}

Terrestrial isopods belonging to the Order Isopoda, Suborder Oniscidea Latreille, 1817, or woodlice, are usually confined to damp habitats, but despite this are widespread in the steppes, semi-deserts and deserts (Borutzky 1948). Almost all families of terrestrial isopods known in the Palaearctic can be found in the zones of steppes and deserts. In arid zones, woodlice inhabit artificially irrigated areas of the desert, where they can be found in large numbers in the soil layer or on the soil surface. During the daytime, they can be found beneath leaves, boards and debris. Woodlice emerge from their shelters in the evening in search of food. In undisturbed biotopes exposed to high levels of solar radiation, woodlice hide beneath wet objects, such as fresh animal droppings, heaps of brushwood or deep in the soil in the tunnels of gerbils, ground squirrels and other vertebrates. Woodlice obtain sufficient moisture in dry habitats via the consumption of leaves and vegetation. When encountering cultural plants, woodlice can damage these, causing losses to agriculture (Borutzky 1978a). Woodlice actively participate in the processes of restoration of natural vegetation in deserts. They primary function is the decomposition of litter, the remnants of grasses and hemi-shrubs, which are collected on the surface. Woodlice actively mix layers of soil, depositing soil from the lower horizons on the surface and by that promote the formation of new islands of vegetation in the deserts (Dimo 1955).

In this paper, we summarized literature data and results of our study of the fauna and distribution of terrestrial isopods of the steppe zone of Kazakhstan. All woodlice were collected by Tatyana M. Bragina, and identified by Dilyara D. Khisametdinova.

\section{Methods}

\section{Study site}

This study was conducted during 2013-2014 in the Kostanay Oblast, located in the steppe zone of Kazakhstan. The northern part of the Oblast occupies the southeastern edge of the West Siberian Plain. Most of the Oblast is located on the Turgai Plateau; in the west, it extends to the undulating plain of the Trans Ural Plateau, and in the southwest, to the foothills of the Kazakh hills (Tikhonov et al 1963). In total, the area of the Oblast covers more than 196 thousand sq. $\mathrm{km}$ (or 19.6 million hectares). The length of the region, from north to south, is over $700 \mathrm{~km}$, and the breadth, from east to west, is $250-400 \mathrm{~km}$. The climate is continental. The temperature increases from north to south, and the amount of precipitation de- creases. The average annual temperature gradient from the north to the south of the area ranges from $-6.9^{\circ} \mathrm{C}$ to $-1{ }^{\circ} \mathrm{C}$, the July average from $+19.3^{\circ} \mathrm{C}$ to $+25.1{ }^{\circ} \mathrm{C}$, and the January average from $-18{ }^{\circ} \mathrm{C}$ to $-8.2^{\circ} \mathrm{C}$. Annual precipitation ranges from $390 \mathrm{~mm}$ in the north to $159 \mathrm{~mm}$ in the south. Due to the diversity of geomorphological, climatic, soil conditions and vegetation in the region, the regular changes of the landscapes are well-defined from forest-steppe to moderately dry and dry steppes, desert steppes, clay and sandy deserts (Bragina 2007).

We investigated the Naurzum National Nature Reserve and Altyn Dala National Nature Rezerve areas (Figure 1), which lie in the Northern and Southern Turgai physiographic provinces of the West Siberian region of the Kazakhstan steppe zone of Eurasia, in the center and south of the Kostanay Oblast.

In the Naurzum National Nature Reserve, the study area was located in the southern part of the Turgai Plateau at 260-290 $\mathrm{m}$ above sea level. The average annual temperature is $1.33^{\circ} \mathrm{C}$, and annual precipitation is 240 $260 \mathrm{~mm}$ (Bragina 2009). We investigated Stipa lessingiana steppe. The vegetation is characterized by xerophytic species of bunch grass, such as Stipa lessingiana, S. capillata, Festuca valesiaca, loose bunch grasses, such as Agropyron pectinatum, and rhizome grasses, such as Leymus ramosus (Rachkovskaya \& Bragina 2012, Bragina 2016). A colony of marmots inhabits this steppe.

The area of the Altyn Dala National Nature Reserve (Figure 2), where woodlice were collected, belongs to the desert steppes (or northern deserts) on brown soils (the vegetation complex includes Artemisia gracilescens, A. pauciflora, Nanophyton erinaceum, Poa bulbosa, sagebrush Anabasis salsa (Anabasis salsa, A. pauciflora, A. gracilescens). Also it includes sites with Anabasis aphylla, Atriplex cana, A. pauciflora communities on small patches of solonetz and salines, in combination with A. semiarida and Stipa sareptana communities on highly solonetz loamy soils and small clay hills with burrows of the yellow ground squirrel (suslik) Spermophilus fulvus Licht. (Rachkovskaya \& Bragina 2012).

Near the river Uly-Zhilanshik, there is complex vegetation (Figure 2) with Festuca valesiaca, Artemisia gracilescens, A. pauciflora, Nanophyton erinaceum and Poa bulbosa.

The aim of the study was to identify the species composition of the terrestrial isopods and some information about their lifestyle in the region.

\section{Sampling}

Specimens of terrestrial isopods were collected by hand, and by using 0.51 plastic pitfall traps with ethylene glycol as a preservative fluid. In this study, no quantitative accounting was conducted. Pitfall traps without roofs 


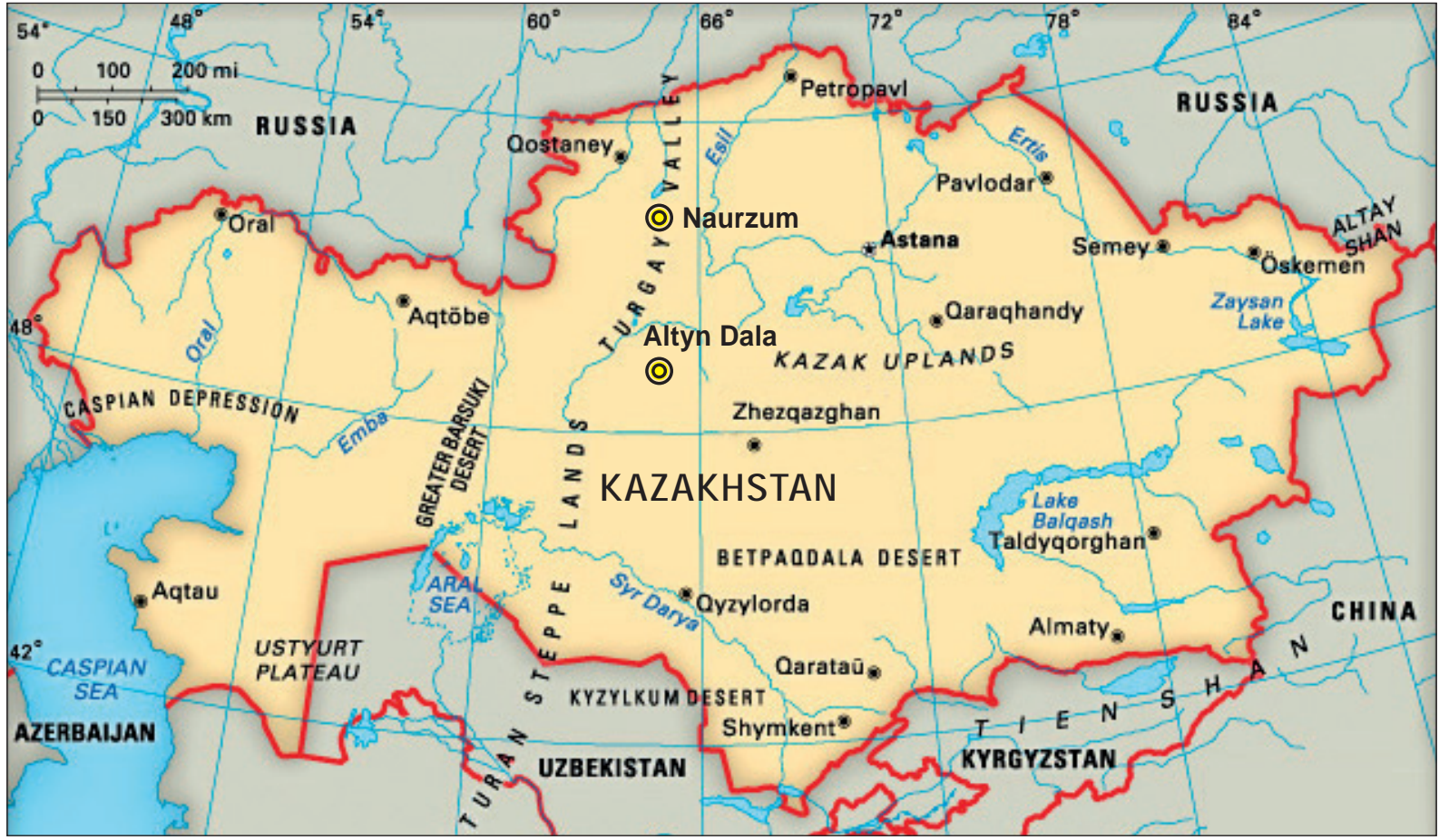

Figure 1: The investigated area with the location of the Naurzum Reserve and the Altyn Dala Reserve. Kostanay Oblast, Kazakhstan. Slika 1: Preučevano območje z lokacijama rezervatov Naurzum in Altyn Dala. Oblast Kostanaj, Kazahstan.

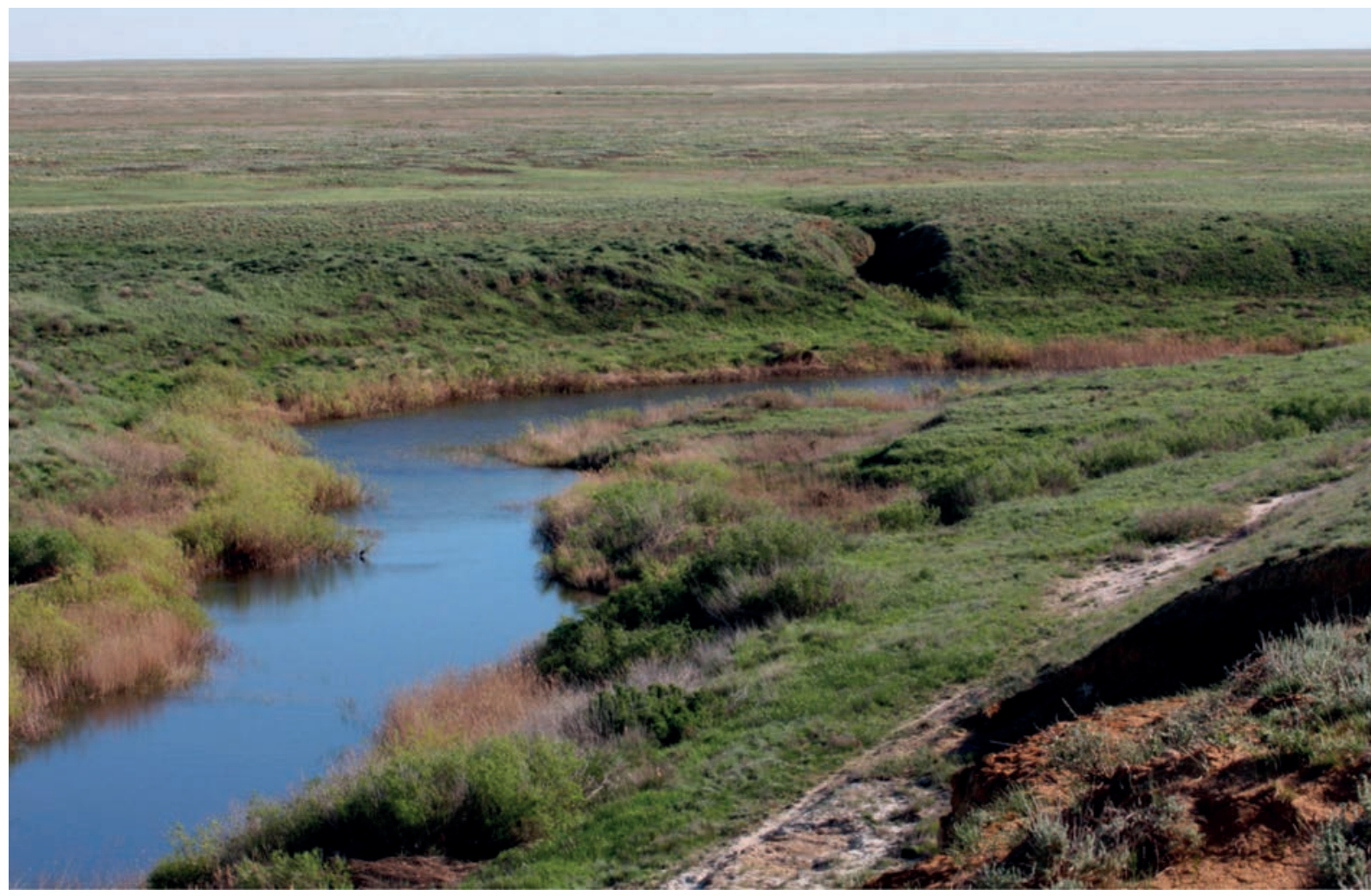

Figure 2: River Uly-Zhilanshik. Kostanay Province. State Nature Reserve "Altyn Dala". Kazakhstan. 10.05.2013. Photo by Tatyana M. Bragina. Slika 2: Reka Uly-Zhilanshik. Provinca Kostanaj. Državni naravni rezervat "Altyn Dala”. Kazahstan. 10.05.2013. Foto: Tatyana M. Bragina. 
were used during short-term sampling visits to the territory (1-3 days) or for a longer period, mainly in the territory of the Altyn Dala Reserve (desert steppes) $\left(50^{\circ} \mathrm{N} 64^{\circ} \mathrm{E}\right)$ and the Naurzum Reserve (moderatelydry and dry steppes). As a rule, a transect of ten traps was installed at a distance of ten meters apart. Trapping was conducted in the years 2013-2014 and the samples preserved in 70\% ethanol. From May to October 2013, 1200 trap-days were used in sites representing a total of seven biotopes. A total of 397 individuals of woodlice of different stages and both sexes were collected and sorted. Hand-harvesting was also used for the litter, detritus and soil (e.g., soil from rodent burrows) (Ghilyarov 1965, Byzova et al. 1987, Anderson \& Ingram 1993) to study the soil macrofauna of the region (Bragina 2004b). In the Naurzum National Nature Reserve $\left(51^{\circ} \mathrm{N} 64^{\circ} \mathrm{E}\right)$ and surrounding areas, we recorded a total number of individuals of woodlice in a sample per $0.25 \mathrm{~m}^{2}$ (Bragina 2004a, 2004b, 2016; Demina \& Bragina 2014). Species were identified according to the key of woodlice (Borutzky 1948, 1978).

\section{Results}

Taxonomic part

Order ONISCIDEA

Group Crinocheta

Family AGNARIDAE

Genus Hemilepistus Budde-Lund, 1879

Hemilepistus ruderalis (Pallas, 1771)

SYN. - Oniscus ruderalis, Porcellio pallasii

Material examined. $2 \hat{\jmath}, 2$ $ᄋ$, Kazakhstan, Kostanay Oblast, Zhangeldy District, National Nature Reserve "Altyn Dala", near the old wintering site Altybai, 12. V. 2013; 4 ふึ, 3 우, Kazakhstan, Kostanay Oblast, Amangeldy District, National Nature Reserve "Altyn Dala", near Rakhmet old village (now destroyed), bank of the river Uly-Zhilanshik, near holes of yellow ground squirrel (suslik) Spermophilus fulvus (Lichtenstein, 1823), from clay soil, 10. V. 2013; 2 ふ઼, 2 우, Kazakhstan, Kostanay Oblast, Amangeldy District, National Nature Reserve "Altyn Dala", near Djarkuy damp, in holes of yellow ground squirrel (suslik) Spermophilus fulvus, clay soil, 11. V. 2013; 1 §,, 1 ㅇ, Kazakhstan, Kostanay Oblast, Amangeldy District, National Nature Reserve "Altyn Dala", bank of the river Uly-Zhilanshik, pitfall traps, 25. V. 2013; 2 우, Kazakhstan, Kostanay Oblast, Amangeldy District, National Nature Reserve "Altyn Dala", bank of the river Uly-Zhilanshik, 12. V. 2013; 18 ô, 15 o 9 , Kazakhstan, Kostanay Oblast, Amangeldy District, National Nature Reserve "Altyn Dala", bank of the river Uly-Zhilanshik, saline alkali soil, pitfall traps,

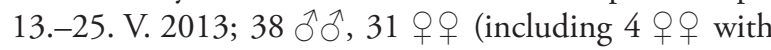
marsupia), Kazakhstan, Kostanay Oblast, Amangeldy District, National Nature Reserve "Altyn Dala", bank of the river Uly-Zhilanshik, nearby vill. Rakhmet, gramine-

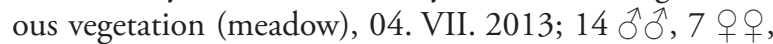
Kazakhstan, Kostanay Oblast, Amangeldy District, National Nature Reserve "Altyn Dala”, old village Ayurkum, meadow (with mushrooms Agaricus sp.), 05. VII. 2013; 37 ふ઼઼, 18 우 (including 15 우 with marsupia), Kazakhstan, Kostanay Oblast, Amangeldy District, National Nature Reserve "Altyn Dala", bank of the river UlyZhilanshik, plant association with Anabasis salsa, pitfall traps, 04. VII. 2013; $8 \hat{\jmath} \widehat{\jmath}, 3$ 우 (including 1 우 with marsupium), Kazakhstan, Kostanay Oblast, Amangeldy District, National Nature Reserve "Altyn Dala”, near Rachmet old village, clay small hill near the river Uly-Zhylanshik, plastic pitfall, 04. VII. 2013; 2 ふึ, 3 우, Kazakhstan, Kostanay Oblast, Amangeldy District, National Nature Reserve "Altyn Dala”, old village Ayurkum, near small pond, 04. VII. 2013; $4 \hat{\jmath} \widehat{\jmath}$, Kazakhstan, Kostanay Oblast, Amangeldy District, National Nature Reserve "Altyn Dala", near Rachmet old village, bank of the river Uly-Zhilanshik, 04. VII. 2013.

In spring 2013, specimens of this species were found from all the surveyed areas of the National Natural Reserve "Altyn Dala". We examined 54 samples of this species. The sex ratio was 1:1. Females with marsupia were absent during this period. This suggests that the period of reproduction in this species in the area had not yet begun. During summer, 185 specimens of this species were recorded. In early July, there were 20 (24\%) females with marsupia. The abundance of males was greater than that of females during this period. Juveniles were not found in July.

Bibliography: Pallas 1771, Brandt 1833, Budde-Lund 1885, Borutzky 1945, 1978b.

Hemilepistus ruderalis (Pallas, 1771) was identified using identification keys from Borutzky $(1945,1978 b)$ and Khisametdinova (2014) (Figure 3).

Distribution: according to Schmalfuss (2003a), the distribution of this species includes the Crimea, the Caucasus and Turkmenistan. Borutzky (1948) pointed out that representatives of the genus are known from the deserts of the Volga region, the Caucasus, Central Asia, Afghanistan, Iran, Asia Minor, and North Africa, whereas in Western Europe this genus is absent due to the lack of suitable ecological conditions. It has been reported from West Kazakhstan (Khisametdinova 2011). This record was the first for this species for Central Kazakhstan and the National Natural Reserve "Altyn Dala" (Bragina \& Khisametdinova 2014). 

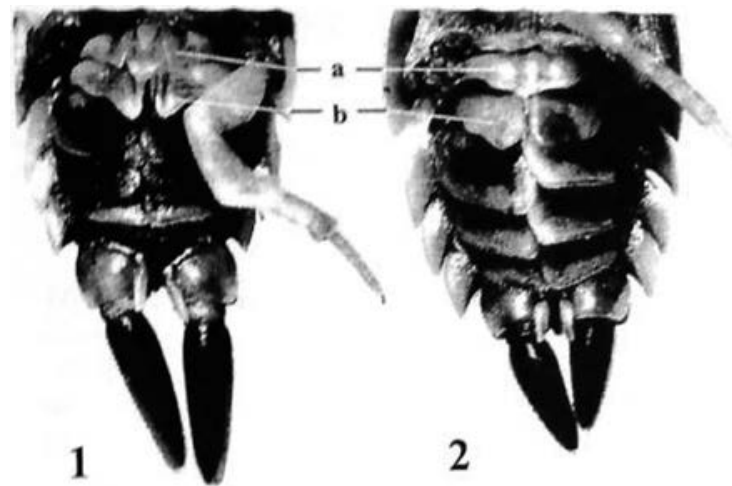

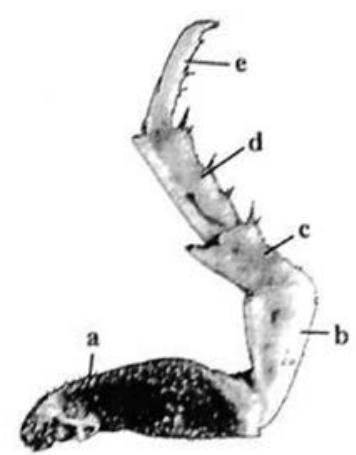

3

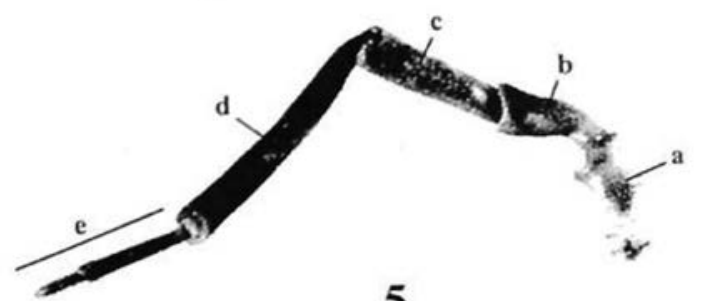

5

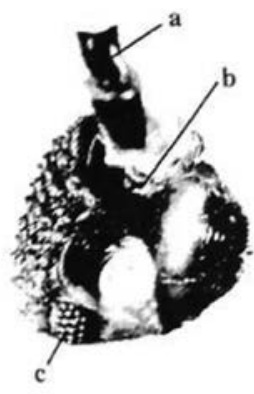

4
Figure 3: Hemilepistus ruderalis (Pallas 1771): $1-\not 2-q$; a,b first and second pleopods (on the ventral side); 3 - VII pereopod $\widehat{\delta}$ : $\mathrm{a}$ - basipodite, $\mathrm{b}$ - ischiopodite, $\mathrm{c}$ - meropodite, $\mathrm{d}$ - carpopodite, e-propodite; 4 - head: a - antennae II, b - antennae I, c - eye; 5 - antennae II: a-d - segments of scape; e - segments of flagellum (from Khisametdinova 2014).

Slika 3: Hemilepistus ruderalis (Pallas 1771): $1-\hat{\delta} 2-q$; a, b - prva dva para zadkovih nožic (pogled s trebušne strani); 3 - hodilka VII $\widehat{\delta}$ : a - bazipodit, b - ihiopodit, c- meropodit, d - karpopodit, e propodit; 4 - glava: a - tipalka II, b - tipalka I, c - oko; 5 - tipalka II: a-d - členi osnove; e - členi biča (po Khisametdinova 2014).

Genus Protracheoniscus Verhoeff, 1917

Protracheoniscus almaatinus Borutzky, 1975

Material examined. $1 \hat{\jmath}$, Kazakhstan, Kostanay Oblast, Amangeldy District, National Nature Reserve "Altyn Dala”, nearby Rakhmet old village (now destroyed), bank of the river Uly-Zhilanshik, near holes of yellow ground squirrel (suslik) Spermophilus fulvus (Lichtenstein, 1823), from the clay soil, 10. V. 2013; 2 के, Kazakhstan, Ko- stanay Oblast, Amangeldy District, National Nature Reserve "Altyn Dala", bank of the river Uly-Zhilanshik, saline alkali soil, pitfall traps, 13.-25. V. 2013; 2 우, Kazakhstan, Kostanay Oblast, Amangeldy District, National Nature Reserve "Altyn Dala", bank of the river Uly-Zhilanshik, nearby village Rakhmet, graminoid veg-

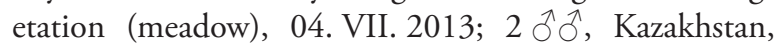
Kostanay Oblast, Amangeldy District, National Nature Reserve "Altyn Dala", old village Ayurkum, meadow (with mushrooms Agaricus sp.), 05. VII. 2013; 2 ふ઼, 3 우 (including 2 우 with marsupia), Kazakhstan, Kostanay Oblast, Amangeldy District, National Nature Reserve "Altyn Dala", old village Ayurkum, nearby small

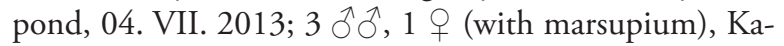
zakhstan, Kostanay Oblast, Amangeldy District, National Nature Reserve "Altyn Dala", Akkum, plant association with Stipa sp., 05. VII. 2013.

This species is probably widely distributed in the investigated sites, but it was few in number and only 25 records have been made during the spring and summer. The species was also found in an apartment building. In spring 2013, only three males of $P$. almaatinus were recorded. During the summer, nine females, three of them with marsupia, were collected.

Protracheoniscus almaatinus Borutzky, 1975 was identified on the basis of descriptions and drawings of this species from Borutzky (1975).

Distribution: Kazakhstan: Almaty region (Schmalfuss 2003a). This is the first time this species has been recorded in Central Kazakhstan and the National Nature Reserve "Altyn Dala”.

Genus Protracheoniscus Verhoeff, 1917

Protracheoniscus major (Dollfus, 1903)

SYN. - Metoponorthus major

Material examined. $6 q 9$ (with marsupia), Kazakhstan, Kostanay Oblast, Amangeldy District, National Nature Reserve "Altyn Dala”, nearby Rakhmet old village (now destroyed), bank of the river Uly-Zhilanshik, near holes of yellow ground squirrel (suslik) Spermophilus fulvus (Lichtenstein, 1823), from clay soil, 10. V. 2013;

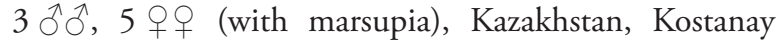
Oblast, Amangeldy District, National Nature Reserve "Altyn Dala", bank of the river Uly-Zhilanshik, nearby village Rakhmet, 10. V. 2013; 1 ○, 2 우 (with marsupia), Kazakhstan, Kostanay Oblast, Amangeldy District, National Nature Reserve "Altyn Dala", bank of the river Uly-Zhilanshik, nearby village Rakhmet, pitfall traps, 25. V. 2013; 11 ふึग, 29 우우 (including 24 우우 with marsupia), Kazakhstan, Kostanay Oblast, Amangeldy District, National Nature Reserve "Altyn Dala", bank of the river Uly-Zhilanshik, saline alkali soil, pitfall traps, 
13.-25. V. 2013; 5 ふึે, 13 우 (including 12 우 with marsupia), Kazakhstan, Kostanay Oblast, Amangeldy District, National Nature Reserve "Altyn Dala", bank of the river Uly-Zhilanshik, nearby village Rakhmet,

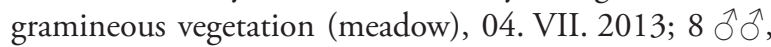
6 우우 (including 6 우 with marsupia), 8 juv., Kazakhstan, Kostanay Oblast, Amangeldy District, National Nature Reserve "Altyn Dala", bank of the river Uly-Zhilanshik, plant association with Anabasis salsa, pitfall traps, 04. VII. 2013; 3 ठึ, 1 ㅇ (with marsupia), Kazakhstan, Kostanay Oblast, Amangeldy District, National Nature Reserve "Altyn Dala", near Rachmet old village, clay small hill near the river Uly-Zhylanshik, pitfall, 04. 07. 2013; $4 \hat{\jmath} \widehat{\partial}, 3$ 우 9 (with marsupia), 2 juv., Kazakhstan, Kostanay Oblast, Amangeldy District, National Nature Reserve "Altyn Dala", bank of the river Uly-Zhilanshik, nearby village Rakhmet, 1 ㅇ (with marsupium), Kazakhstan, Kostanay Oblast, Amangeldy District, National Nature Reserve "Altyn Dala", nearby village Rakhmet, steppe pasture, 04. VII. 2013.

The woodlouse Protracheoniscus major was collected in different habitats of the shore of the river Uly-Zhilanshik. In spring 2013, 57 specimens of this species were collected, of which 37 were females with marsupia. During this period, males were three times less than females. In the summer, 99 specimens of $P$. major were found, of which $46 \%$ were females with marsupia, and the proportion of juveniles was $10 \%$. Thus, it can be noted that, compared with $H$. ruderalis, in this species the reproduction period occurs at an earlier date and for a more extended period. Generally during active period males were four times less than females.

This species was identified using Gruner (1966a, b) with drawings and descriptions of Protracheoniscus major. Bibliography: Dollfus in Dyduch 1903, Strouhal 1929 (sub P. asiaticus), Semenkevitsh 1931, Gruner 1966a, 1966b, Dominiak 1970, Schmölzer 1974, Jędryczkowski 1979, Ilosvay 1985, Flasarová 1986, 1988, 1991, 1995, 1999, Kwon 1993.

Distribution: from southeastern Germany to Central Asia ("Turkestan" (Schmalfuss 2003), probably Turkestan - South Kazakhstan region (remark by authors), Turkmenistan (Schmalfuss 2003a), and the south of the European part of Russia (Knipovich 1890-1907, Khisametdinova 2011). The authors report this species for the first time in Central Kazakhstan and in the National Nature Reserve "Altyn Dala".

Genus Desertoniscus Verhoeff, 1930

Desertoniscus subterraneus Verhoeff, 1930

Material examined. 1 ก, 1 , , Kazakhstan, Kostanay Oblast, Amangeldy District, National Nature Re- serve "Altyn Dala", nearby Rakhmet old village (now destroyed), bank of the river Uly-Zhilanshik, near holes of yellow ground squirrel (suslik) Spermophilus fulvus (Lichtenstein, 1823), in clay soil, 10. V. 2013; 4 q 9 , Kazakhstan, Kostanay Oblast, Amangeldy District, National Nature Reserve "Altyn Dala", bank of the river UlyZhilanshik, plant association with Anabasis salsa, pitfall traps, 04. VII. 2013. Only six specimens of Desertoniscus subterraneus were collected for the entire period of investigation in the reserve "Altyn Dala" during 2013.

Bibliography: Verhoeff 1930, Borutzky 1945, 1959, 1978.

Desertoniscus subterraneus was identified on the basis of descriptions, drawings and the identification key for $D e-$ sertoniscus spp. from Borutzky (1978).

Distribution: According to Borutzky (1959, 1978), this species was recorded in Uzbekistan, Fergana region, near Urgench; in Tajikistan, Fergana Valley and Dushanbe region; in Turkmenistan, near the town Tagtabazar; in Kyrgyzstan, Teskey Ala-Too and Issyk-Kul Region. This species of woodlouse inhabits open sites. To avoid sunlight, they burrow deep into the soil or hide under moist shelter, such as fresh dung, heaps of brushwood and other debris (Borutzky 1948).

\section{Family CYLISTICIDAE}

Genus Parcylisticus Verhoeff, 1943

Parcylisticus dentifrons (Budde-Lund, 1885)

Material examined. 1 ○े, Kazakhstan, Kostanay Oblast, Auliekol District, Naurzum National Nature Reserve, Tersek, Stipa lessingiana steppe, from holes of marmot (Marmota bobak (Statius Muller, 1776), 17. V. 2014.

Bibliography: Budde-Lund (1885); Borutzky (1961, 1972, 1977); Schmalfuss (1989); Schmalfuss (2003); Jeppesen (2000).

Parcylisticus dentifrons was identified on the basis of descriptions and drawings of this species from Schmalfuss (1989).

Distribution: According to Schmalfuss (1989, 2003b), this species was recorded in the Stavropolsky kray, and the republics of Kabardino-Balkar, Ingushetia, Chechenia, Dagestan and North Ossetia-Alania (the Northern Caucasus, Russia and Azerbaijan). Here it is recorded for the first time in Kazakhstan, in the central part of Kostanay Oblast and in the Naurzum Reserve.

\section{Family PORCELLIONIDAE}

Genus Porcellio Latreille, 1804

Porcellio scaber Latreille, 1804

Material examined. $1 \hat{\jmath}$, Kazakhstan, Kostanay Oblast, Naurzum District, village Karamendy, in dwelling house, 20. IV. 2014. 
Distribution: Europe, except the southeastern part, introduced worldwide (Schmalfuss, 2003a), known from Rostov Region (SW-Russia) (Khisametdinova 2007, 2011). First record for Kazakhstan.

In addition, we can say that the total abundance of woodlice in the Naurzum National Nature Reserve was not more than two individuals per $0.25 \mathrm{~m}^{2}$ (Bragina 2004a, 2004b, 2016; Demina \& Bragina 2014).

\section{Discussion}

An inventory of the woodlouse fauna of the former USSR yielded 190 species (Kuznetsova, Gongalsky 2012), but only 12 species were recorded from the territory of Kazakhstan. One species, Cylisticoides angulatus Schmalfuss, 2003, presented in the work of Kuznetsova, Gongalsky (2012) for the Astana area, is probably erroneous. This species was found to the west of the city of Astara in Azerbaijan (Schmalfuss 1989, 2003b), in the forest, and not in Astana (steppe zone). In addition, Schmalfuss (2003b) indicates a probable record of this species near Sochi (authors comment: most likely it was introduced there), but the specimen was female, so there is no precise confirmation. Hemilepistus fedtschenkoi (Uljanin 1875) was recorded in Semipalatinsk (East Kazakhstan, steppe zone) (Kuznetsova \& Gongalsky 2012). Three species, H. nodosus Budde-Lund, 1885; $H$. pavlovskii Borutzky, 1954; $H$. rhinoceros Borutzky, 1958, were given without location details (Kuznetsova, Gongalsky 2012). Other species were recorded from outside the steppe zone in Kazakhstan.

On the surrounding steppe and forest-steppe areas, few species of woodlice were recorded (Khisametdinova et al. 2016): Porcellio laevis Latreille, 1804 (Porcellionidae) recorded on an unspecified date between 1897 to 1917 by an unknown collector in the Barnaul Uyezd (foreststeppe and steppe zone), and four species were recorded in the south of Western Siberia (forest-steppe), though all four species Porcellio laevis Latreille, 1804, Trachelipus rathkii (Brandt, 1833), Cylisticus convexus (De Geer, 1778) and Trichoniscus pygmaeus Sars, 1898, are associated with synanthropic habitats.

With literature and our data on the territory of Kazakhstan, 16 species of woodlice have been recorded currently (Table 1).

Table 1: List of woodlouse species from the territory of Kazakhstan (resource: Kuznetsova \& Gongalsky (2012), Borutzky (1945, $1954,1955,1958,1961,1975,1978)$ ) with the inclusion of new records (four species) from this study. Abbreviations:

Az - Azerbaijan, Bl - Belarus, Iq - Iraq, In - Iran, Kz - Kazakhstan, Kg - Kyrgyzstan, Ru - Russia, Td - Tajikistan, Tu - Turkmenistan, Ua - Ukraine, Uz - Uzbekistan.

Tabela 1: Seznam mokric z območja Kazahstana (viri: Kuznetsova \& Gongalsky (2012), Borutzky (1945, 1954, 1955, 1958, 1961, 1975, 1978)) z vključenimi novimi podatki (štiri vrste) iz te raziskave. Okrajšave: Az - Azerbajdžan, Bl - Belorusija, Iq - Irak, In - Iran, Kz - Kazakstan, Kg - Kirgizistan, Ru - Rusija, Td - Tadžikistan, Tu - Turkmenistan, Ua - Ukrajina, Uz - Uzbekistan.

1 Desertoniscus subterraneus Verhoeff, 1930

2 D. zhelochovtzevi Borutzky, 1945

3 Hemilepistus crenulatus (Pallas, 1771)

4 H. fedtschenkoi (Uljanin, 1875)

$5 \quad$ H. klugii (Brandt, 1833)

6 H. nodosus Budde-Lund, 1885

7 H. pavlovskii Borutzky, 1954

8 H. rhinoceros Borutzky, 1958

9 H. ruderalis (Pallas, 1771)

10 Ligidium margaritae Borutzky, 1955

11 Parcylisticus dentifrons (Budde-Lund, 1885)

12 Porcellio scaber Latreille, 1804

13 Protracheoniscus almaatinus Borutzky, 1975

14 P. major (Dollfus, 1903)

15 P. orientalis (Uljanin, 1875)
Kg; Tu: (Kizil-arvat); Td: Samgar massif ; Kz: South Turgai (Central Kazakhstan, Kostanay region) $=$ new for $K z$ !

Kz: Akkul

Kz: Ustyrt, Betpak-Dala; Iq; In; Td: Samgar massif; Tu: Central Karakum, KyzylArvat; Uz: Zakaspiysk, Fergana regions; $\mathrm{Kg}$

Kz: Semipalatinsk; Tu: Krasnovodsk; Uz: Bukhara, Samarkand, Syrdaryinsk, Zakaspyisk regions

Kz: Mangyshlak

$\mathrm{Tu} ; \mathrm{Kz}$

$\mathrm{Kz}$

$\mathrm{Kz}$

Kz: Djanybek (West Kazakhstan); South Turgai (Central Kazakhstan, Kostanat region)

Kz: Alma-Ata region

Kz: Central Kazakhstan: Naurzum Reserve, Kostanay region = new for $K z !$ Kz: Central Kazakhstan: village near Naurzum Reserve, Kostanay region = new for $\mathrm{Kz}$ !

Kz: Alma-Ata; South Turgai (Central Kazakhstan, Kostanay region)

Ru: Rostov region; Ua: Kiev; Kz: South Turgai (Central Kazakhstan,

Kostanay region) $=$ new for $K z$ !

Az: Baku, Mardakert; Bl: Berezinsky reserve; Kz: Mangyshlak; Tu: Bugdaily;

Ru: Moscow, Orenburg, Primorie regions; Ua: Kremenetz,

Odessa regions, Uz: Nukus; Zakaspyisk region

Kz: Alma-Ata region, Uzun-Agach; Ru: Moscow region? 
In the south of the investigated area, we recorded four species (Hemilepistus ruderalis, Protracheoniscus major, P. almaatinus, Desertoniscus subterraneus), belonging to the family Agnaridae from the group Crinocheta (Kostanay Oblast, Southern Turgai, National Nature Reserve "Altyn Dala") (Bragina \& Khisametdinova 2014). All these species are typical inhabitants of deserts. In addition, the genus Desertoniscus is endemic to the Eurasian desert zone (Borutsky 1948). The aurthors recorded D. subterraneus Verhoeff, 1930 and P. major (Dollfus, 1903) for the first time from Kazakhstan. Also the species Parcylisticus dentifrons and the synanthropic form of Porcellio scaber (Kostanay Oblast, Northern Turgai) were recorded for the first time from Kazakhstan. Parcylisticus dentifrons, represented by a single record in this study. Specimens of this genus are distributed in the southeastern Mediterranean, and they are numerous in the North Caucasus, Trans Caucasia region, Dagestan and Azerbaijan, and also occur in records from Kalmykia. Porcellio scaber is a highly typical synanthropic species and it occurs everywhere outside of Northern and Central Europe. In the future, we will give attention in our research to the anthropogenic fauna of the region of the steppe zone. In particular, the fauna of the Rostov Region (eastern European steppes) of twenty one species of terrestrial isopods, which includes twenty species that were recorded in the anthropogenic landscape, while eight species were only recorded in the steppe landscape (Khisametdinova 2011).

\section{Conclusion}

The woodlouse fauna of many parts of the steppe zone is still largely undiscovered. As the result of our investigation, six species of woodlouse (Crustacea: Isopoda: Oniscidea), belonging to five genera and three families, were recorded from steppe in Kazakhstan (central and southern part of Kostanay Region). On the territory of Kazakhstan, 16 species of woodlouse have been recorded. Further studies are needed in other regions of the Asian steppes to give a representative overview of the distribution of terrestrial isopods, as well as synanthropic species of the region.

\section{Acknowledgments}

We are very grateful to all the supporters who assisted in the field observations, especially Dr. Yevgeny Bragin. We also thank everybody who contributed to this work by discussing and providing comments, especially Dr. Orsolya Valkó and Dr. Stephen Venn, for editorial support, linguistic editing and handling. We thank the Eurasian Dry Grassland Group (EDGG) for the possibility to publish this paper.

\section{References}

Anderson, J. M. \& Ingram, J. S. I. 1993: Tropical soil biology and fertility: a handbook of methods. Second edition. CAB International, The Cambrian News, Aberystwyth, United Kingdom, 221 pp.

Tikhonov, I. S. et al. (eds). 1963: Atlas of the Kostanay Oblast [in Russian]: GUGK GGK USSR, Moscow, 79 pp.

Borutzky, E. V. 1945: Fauna of woodlice of the Turkmenistan and neighboring regions of Central Asia [in Russian]. Uchenye Zapiski Moskovskogo Gosudarstvennogo Universiteta. 83: 165-202.

Borutzky, E. V. 1948: Woodlice - Isopoda [in Russian]. In: Pavlovsky E. N., Vinogradov B. S. (eds.): Fauna of USSR. Volume 2. The Desert Zone M.-L .: Publishing House of the Academy of Sciences of the USSR, pp. 308-311.

Borutzky, E. V.1954: New species of genus Hemilepistus (Isopoda terrestria) from the East Kazakhstan [In Russian]. Zool. Journal 33: 477-479.

Borutzky, E. V. 1955: New species of Ligidium (Isopoda terrestria) from Middle Asia [in Russian]. Byulleten moskovskogo Obshchestva Ispŷtateleŭ Prirodŷ. Biologia 60(1): 59-61.

Borutzky, E. V. 1958: Soil woodlice of the genus Hemilepistus (biology and systematics) [Russian with English summary]. Zool. Journal37 (10): 1126-1145.

Borutzky, E. V. 1959: Materials on the fauna of terrestrial isopods (Isopoda terrestria) in the Kirghiz SSR [Russian with English summary]. Zool. Journal38(7): 1006-1117.

Borutzky, E. V. 1961: New and unknown species of the genus Cylisticus (Isopoda terrestria) from the USSR [in Russian]. Sbornik Trudov Zoologicheskogo Muzeya, (8): 29-46.

Borutzky, E. V. 1972: List of holotypes of Isopoda Oniscoidea in the Zoological Museum of the Moscow University [in Russian]. Sbornik Trudov Zoologicheskogo Muzeya 12: 191-200.

Borutzky, E. V. 1975: New species of woodlice of genus Protrachoniscus [in Russian]. Zool. Journal54(12): 1783-1796.

Borutzky, E. V. 1977: New species of the genus Cylisticus (Isopoda, Oniscoidea, Cylisticidae) [in Russian]. Zool. Journal56: 28-37.

Borutzky, E. V. 1978a: The genus Desertoniscus Verhoeff, 1930 [in Russian]. Sbornik Trudov Zoologicheskogo Muzeya16: 3-21.

Borutzky, E. V. 1978b: Systematics and ecology of the desert isopod subgenus Hemilepistus s. str. Budde-Lund, 1885 (Isopoda, Porcellionidae) [in Russian]. Sbornik Trudov Zoologicheskogo Muzeya16: 22-65.

Bragina, T. M. 2004a: Comparative analysis of the population of soil invertebrates of steppes and fallow lands in the sub zone of moderately dry steppe of Kazakhstan [in Russian]. Proceedings of the National Academy of Sciences of Kazakhstan. Biological and Medical Series 4: 25-30.

Bragina, T. M. 2004b: The pattern of changes in soil fauna at desertification by example of dry steppe zone of the Central Asia, Doctoral (Biol.) Dissertation [in Russian], A.N. Severtsov Institute of Ecology and Evolution, Moscow, $324 \mathrm{pp}$.

Bragina, T. M. 2007: Protected areas of Kazakhstan and prospects of the establishment of ecological network (with the legislative framework in the field of specially protected natural areas) [in Russian]. Kostanay Printing House, Kostanay, 164 pp.

Bragina, T. M. 2009: Naurzum Ecological Network (exploration history, current status and long-term conservation of biological diversity in the region of representation of natural World Heritage Site by UNESCO). Kostanaipoligrafiya, Kostanay, 200 pp. 
Bragina, T. M. \& Khisametdinova, D. D. 2014: The fauna of terrestrial isopods (Crustacea, Isopoda) of the State Natural Reserve "Altyn Dala" [in Russian]. In: Successes of formation and functioning of the network of specially protected areas and the study of biological diversity. Proceeding of the International scientific-practices. conference, Kostanay, 26-27 February, 2014. KSPI, Kostanay, pp. 119-123.

Bragina, T. M. 2016: Soil macrofauna (invertebrates) of Kazakhstanian Stipa Tessingiana dry steppe. Hacquetia 15(2): 105-112.

Brandt, I. F. 1833: Conspectus Monographiae Crustaceorum Oniscodorum Latreillii. Byulleten moskovskogo Obshchestva Ispŷtateleı̌ Prirodŷ 6: 171-193.

Budde-Lund, G. 1885: Crustacea Isopoda terrestria per familias et genera et species descripta, Copenhagen, 319 pp.

Byzova, Y. B., Ghilyarov, M. S., Dunger, V., Zakharov, A. A., Kozlovskaya, L. S., Korganova, G. A., Mazantseva, G. P., Meletsis, V. P., Prasse, I., Puzachenko, I. G., Rybalov, L. V. \& Striganova, B. R. 1987: Quantitative Methods in Soil Zoology [in Russian], Science, Moscow, 288 pp.

Demina, O. \& Bragina, T. 2014: Fundamental basis for the conservation of biodiversity of the Black Sea-Kazakh steppes. Hacquetia 13 (1): 201-214.

Dimo, N. A. 1955: Woodlice and their role in pedogenenic process in the deserts. Observations and investigation of the soil fauna [in Russian]. GosIzdat Moldavii, Kishinev, pp. 115-125.

Dominiak, B. 1970: Badania nad równonogami Polski. Fragmenta faunistica (Warsaw) 15: 401-472.

Dyduch, T. 1903: Materialien zu einer Isopodenfauna Galiziens. Bulletin international de l'Académie des Sciences et des Lettres de Cracovie 1903: 61-64.

Flasarová, M. 1986: Isopoda (Asellota, Oniscoidea) of the Little Carpathians. In: NOSEK, J. (ed.): The Soil Fauna of the Little Carpathians, pp. 183-216; Bratislava.

Flasarová, M. 1988: Zur Kenntnis der Isopoden Mittelböhmens (Crustacea, Isopoda, Asellota et Oniscidea). Faunistische Abhandlungen (Dresden) 15: 119-130.

Flasarová, M. 1991: Kartierung der Isopoden in Nordwestböhmen (Czechoslowakia). - Proceedings of the 4thECE/XIII. SIEEC, Gödöllö 1991: 708-714.

Flasarová, M. 1995: Die Isopoden Nordwestböhmens (Crustacea: Isopoda: Asellota et Oniscidea). Acta Scientarum naturalium (Brno) 29: $1-156$

Flasarová, M. 1999: Bericht über Isopoden (Asellota et Oniscidea) im slowakischen Donaugebiet. Acta Musei nationalis Pragae, Series B, 54: 61-78.

Gruner, H. 1966a: Die Tierwelt Deutschlands. 53. Teil. Krebstiere oder Crustacea. V. Isopoda, 2. Lieferung, Jena, pp. 151-380.

Gruner, H. 1966 b: Über Protracheoniscus asiaticus (Uljanin, 1875) und die verwandten Arten (Isopoda, Oniscoidea). Mitteilungen des zoologischen Museums Berlin 42: 307-319.

Ghilyarov, M. S. 1965: Zoological diagnostic method of soil [in Russian]. Science, Moscow, 278 pp.

Ilosvay, G. 1985: On the isopod, diplopod and chilopod fauna of the Zirc arboretum [Hungarian with English and German summaries]. A Bakony természettudományi kutatásának eredményei 16: 43-50.

Jędryczkowski, W. 1979: Synanthrope Landisopoden (Isopoda,

Oniscoidea) Polens [Polish with Russian and German summary].

Fragmenta faunistica (Warsaw) 25: 95-106.
Jeppesen, P. 2000: Catalogue of terrestrial isopod taxa and type material described by Gustav BUDDE-LUND (Crustacea:Isopoda). Steenstrupia 25: 221-265.

Khisametdinova, D. D. 2007: The woodlice fauna (Isopoda, Oniscidae) of Rostov Region. Proc. of Institutes of Higher Education of Northern Caucasian Region: Nat. Sci. 6: 82-84.

Khisametdinova, D. D. 2014: Identification Key of Terrestrial Isopods (Isopoda: Oniscidea) of Rostov Region. Proc. of Institutes of Higher Education of Northern Caucasian Region: Nat. Sci. 2: 72-76.

Khisametdinova, D. D. 2011: Terrestrial isopods (Isopoda, Oniscidea) of the Rostov Region, SW-Russia. In: Proceedings of the 8th International Symposium of Terrestrial Isopod Biology ISTIB June 19-23, 2011, Hotel Ribno, Bled, Slovenia: 111-113.

Khisametdinova, D. D., Nefediev, P. S., Tuf, I. H. 2016: New records of woodlice in the south of western Siberia, Russia (Isopoda: Oniscidea). Invert. Zool. 13(1): 51-55. doi: 10.15298/ invertzool.13.1.04.

Knipovich, N. M. 1806: Brockhaus and Efron Encyclopedic Dictionary: Vol. 19a, Woodlice.Tipo lithography I. A. Efron, St. Petersburg. pp. 613-614.

Kuznetsova D. M. \& Gongalsky K. B. 2012: Cartographic analysis of woodlice fauna of the former USSR. In: Strus J, Taiti S, Sfenthourakis S (eds): Advances in Terrestrial Isopod Biology. ZooKeys 176: 1-11. doi: 10.3897/zookeys.176.2372.

Kwon, D. 1993: Terrestrial Isopoda (Crustacea) from Korea. Korean Journal of Zoology 36: 133-158.

Pallas, P. 1771: Reise durch verschiedene Provinzen des Russischen Reiches in den Jahren 1768-1774, St. Petersburg vol. 1, 504 pp.

Rachkovskaya, E. I. \& Bragina, T. M. 2012: Steppes of Kazakhstan: diversity and present state. In: Marinus, J. A. Werger, M. \& van Staalduinen, A. (eds.): Eurasian steppes. Ecological problems and livelihoods in a changing world. Springer, Dordrecht, pp. 103-148.

Schmalfuss, H. 1989: Land-Isopoden aus dem Kaukasus-Gebiet. 2. Cylisticus dentifrons Budde-Lund. Stuttgarter Beiträge zur Naturkunde, Serie A, 431: 9 pp.

Schmalfuss, H. 2003a: World catalog of terrestrial isopods (Isopoda: Oniscidea). Stuttgarter Beiträge zur Naturkunde. Serie A. Nr. 654, $341 \mathrm{pp}$.

Schmalfuss, H. 2003b: Terrestrial isopods (Crustacea: Isopoda) from the Caucasus region. 5. Cylisticus Schnitzler, Parcylisticus Verhoeff, Cylisticoides n. gen. Stuttgarter Beiträge zur Naturkunde, Serie A, 647: 38 pp.

Schmölzer, K. 1974: Catalogus Faunae Austriae, Teil 8e, Isopoda, Vienna, pp. 1-16.

Semenkevitsh, J. 1931: Isopoda terrestria der Umgegend von Kiew. Mémoires de la Classe des Sciences naturelles et techniques, Académie des Sciences d'Ukraine Acad. Sci. Ukraine, 5: 3-16.

Strouhal, H. 1929: Über einige Arten der Gattung Protracheoniscus Verh. (Isop. terr.). Annalen des naturhistorischen Museums in Wien 43: $1-12$.

Verhoeff, K. 1930: Über Isopoden aus Turkestan. Zoologischer Anzeiger 91: 101-125. 